\title{
PREFERENCES OF YOUTH IN RELATION TO THE ORIGIN OF BRANDS - ROMANIAN AND FOREIGN - AND ITS MAIN MOTIVATION
}

\author{
Laura Cătălina Țimiraş \\ "Vasile Alecsandri" University of Bacau \\ timiras.laura@ub.ro
}

\begin{abstract}
This paper is based on some results of a direct research conducted among youth 18-30, students of the Faculty of Economic Sciences of the Vasile Alecsandri University of Bacau. The research was conducted in the month of April 2016 on a sample of 100 students selected by group sampling scheme and has an exploratory character offering a guideline on youth preference for Romanian or foreign brands for product categories: food products, alcohol beverages, personal hygiene products, cosmetics, cleaning products, clothing, footwear, consumer electronics and cars. They are also shown and the main reasons underlying preferences in terms of brand origin. The results of study highlights that the youth prefer in a greater extent Romanian food products compared to foreign ones, but, for products encompassing high technology (cars, appliances and electronics) and for fashion products (clothing and footwear) over 50\% of respondents prefer foreign brands.
\end{abstract}

\section{Keywords}

direct research; preferences; reasons; domestic brand; foreign brand

\section{JEL Classification}

M31

\section{Introduction}

The multitude of brands on the market - domestic or foreign - put the consumers in a process of evaluation, according to objective or subjective criteria, acknowledged or not. In the context of the abundance of products, the marketers are working to make their products known, to bring their products closer to consumers, to convince them to buy, to satisfy their tastes in order to generate recurrence acquisition and develop their loyalty over time. Basically, preference for certain product categories is generated by a number of factors related to product (tangible, acorporal and communication components) and to a number of elements related to consumer: his needs, expectations, his tastes, etc.

Preference of Romanian consumer for Romanian or import products was studied by Nielsen in 2008, the results stating that Romanian products are preferred only in foods (53\% of investigated Romanian saying this), but in terms of products for personal care and cleaning, are preferred imported goods (Romanian products are preferred by 22\% and 26\% respectively). (Market Magazine, November 2008)

Another study by MEMRB and published the same year, reveals that only $30 \%$ of the dominant brands in the retail market in Romania (measured by market share) are indigenous. (Market Magazine, June 2008)

Consumer preferences for specific product categories, however, are significantly influenced by age, being well known that young people can have different criteria for choice of different brands. In this context, we aimed to evaluate the extent to which 
the Romanian or foreign brands, by their characteristics, fall in youth preferences for different product categories.

\section{Methodology and limitations of research}

In April of 2016, we conducted a direct research among young people aged 18-30 years, selected from undergraduate students of the Faculty of Economic Sciences of the Vasile Alecsandri University of Bacau. The research was conducted using survey and questionnaire data were completed through self-registration.

We used group sampling scheme, the investigated sample of 100 respondents, being representative exclusively for the population of which it has been extracted.

The research is exploratory, the results - some presented in this paper - may constitute hypotheses for other representative surveys for other collectivities.

Some of the objectives of research was to identify preferences of youth regarding the brand origin - domestic or foreign - for product categories and to identify the main motivations underlying these preferences.

The motivations presented as underpinning the preferences for one or another category of brands, it is based solely on the statements of the respondents, being therefore those which respondents are aware of and those they wanted to declare. But bear in mind that, at the base of individual behavior stay other factors which consumer is not aware of or that he wishes not to declare, context in which in order to identify them one can be use qualitative research methods. (Popescu, 2002)

\section{Youth brand preference in terms of origin}

Referring to food products, we can see that youth generally prefer local brands $(20 \%$ of them prefer Romanian products, compared with only $10 \%$ who prefer foreign brands) although most (55\%) prefer equally Romanian and foreign brands. In fact, this product category is only one of those subject to assessment for which there is a greater orientation towards local brands compared to foreign ones. A relatively high proportion $(15 \%)$ of respondents said they did not know whether Romanian or foreign brands are preferred or could not provide an answer to the question.

In case of alcoholic beverages, $44 \%$ of young people prefer equally the two categories of brands and nearly a quarter prefer foreign brands (basically, the percentage of those who prefer foreign brands is over 3 times higher than the percentage of those who prefer Romanian products). $26 \%$ do not know the origin of their favorite brands or, where appropriate, have not been able to answer / do not have preferences, this percentage having practically the highest values compared to similar products from other categories.

The preference for foreign products for personal hygiene is manifested for a rate of respondents over 5 times higher than those who prefer Romanian products. (41\% versus $8 \%$ ); still, largest category of respondents - $44 \%$ is represented by those who said they prefer both categories of brands.

Foreign brands of cosmetics are appreciated by most young people, with $44 \%$ share, which surpasses 11 times that of those who said they prefer Romanian brands. More than half of the people surveyed said they either prefer both categories of brands (38\%), either do not know the origin of brands or cannot provide an answer on the issue investigated / have no preference.

In the case cleaning products, most young people (53\%) equally prefer investigated brand categories. Similarly, as the case of "alcoholic beverages" category, a significant proportion do not know the origin of the brands or cannot answer / have no preference $(19 \%)$. The gap between those who have expressed a preference for 
foreign brands and those who have expressed a preference for domestic brands is in this case a high one (6 times).

Regarding the clothing and footwear products, there is a relatively identical situation. Most young people prefer foreign brands (53\%) and a low share (1\% and 6\%, respectively) prefers Romanian brands. Compared to other analyzed categories, clothing and footwear products are the category for what most young people were able to express their preference for the origin of the brand, which indicates a higher degree of knowledge of brands. Thus, could not show their preference in terms of brand origin only $5 \%$ of respondents for clothing and $4 \%$ for footwear.

Foreign brands of products which integrate high-technology (electronics and appliances, cars) are also preferred by young people. With $56 \%$ for electronics and appliances, and $62 \%$ for cars, the two product categories recorded the highest percentage of young people who have shown their preference for foreign brands. Regarding the preference for Romanian brands, if for electronics and appliances we found $9 \%$ of respondents who stated that, no respondent prefers Romanian cars. Less than 30\% said that they prefer both brands for these product categories.

Overall, the Romanian food products are those that enjoy the greatest manifestation of preference compared to other categories analyzed, although most young people prefer Romanian and foreign brands alike. In contrast, preference for foreign brands is manifested most intensively (over 50\% of respondents) for passenger cars, electronics and appliances, as well as clothing and footwear. Products categories that most respondents said they preferred both brands are: food products, cleaning products, alcoholic beverages and personal hygiene products. Most of those respondents who were unable to indicate the category of favorite brands, either due to ignorance of their origin or the fact that they were not able to answer / they have no preference, are: alcoholic beverages, cleaning products, food products and cosmetics, attesting the lowest level of knowledge of the brands for these categories (compared to the other products analyzed).

\section{Table 1. Distribution of respondents according to the preference for origin of the brand - domestic or foreign - by product category (\% of total investigated sample)}

\begin{tabular}{|c|c|c|c|c|c|}
\hline Product category & $\begin{array}{l}\text { I prefer } \\
\text { especially } \\
\text { Romanian } \\
\text { brands }\end{array}$ & $\begin{array}{l}\text { I prefer } \\
\text { especially } \\
\text { foreign } \\
\text { brands }\end{array}$ & $\begin{array}{c}\text { I prefer } \\
\text { equally } \\
\text { Romanian } \\
\text { and foreign } \\
\text { brands }\end{array}$ & $\begin{array}{l}\text { I do not know } \\
\text { if favorite } \\
\text { brand / brands } \\
\text { is/are } \\
\text { Romanian or } \\
\text { foreign }\end{array}$ & $\begin{array}{c}\text { Do not } \\
\text { know / No } \\
\text { preference }\end{array}$ \\
\hline $\begin{array}{l}\text { Food products } \\
\text { (excluding alcoholic } \\
\text { beverages) }\end{array}$ & 20 & 10 & 55 & 9 & 6 \\
\hline Alcoholic beverages & 7 & 23 & 44 & 8 & 18 \\
\hline $\begin{array}{l}\text { Personal hygiene } \\
\text { products }\end{array}$ & 8 & 41 & 44 & 6 & 1 \\
\hline Cosmetics & 4 & 44 & 38 & 7 & 7 \\
\hline Cleaning products & 4 & 24 & 53 & 13 & 6 \\
\hline Clothing & 1 & 53 & 41 & 4 & 1 \\
\hline Footwear & 6 & 53 & 37 & 4 & - \\
\hline $\begin{array}{l}\text { Electronics and home } \\
\text { appliances }\end{array}$ & 9 & 56 & 28 & 7 & - \\
\hline Cars & 0 & 62 & 26 & 3 & 9 \\
\hline
\end{tabular}




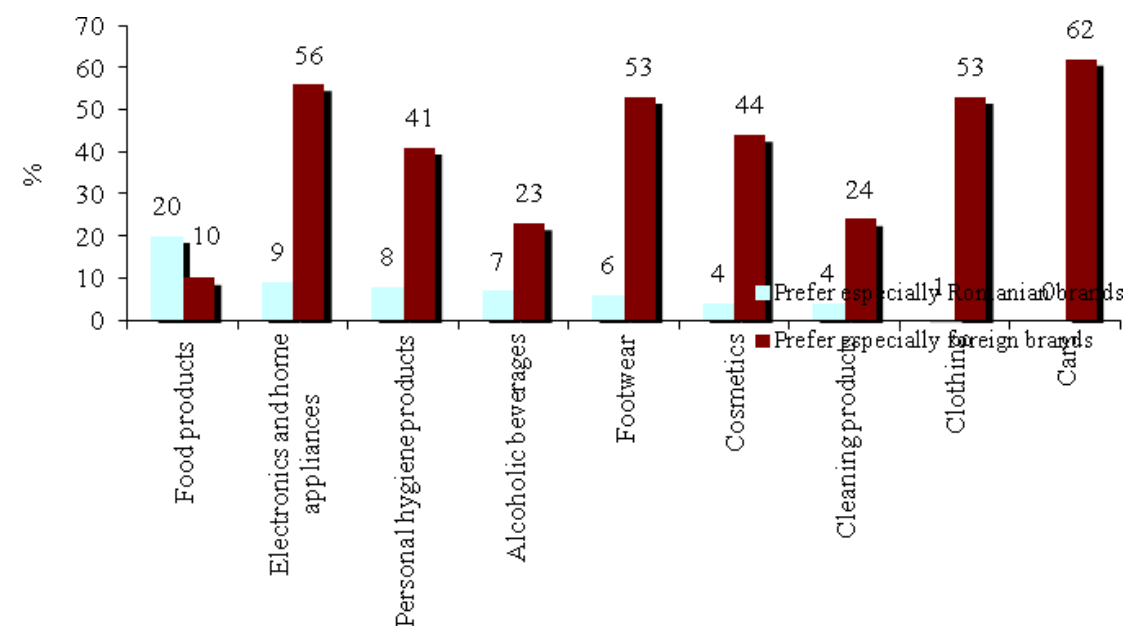

Figure 1. Respondents' preference for local brands and foreign - by product category* (\% of total investigated sample)

* It has been excluded those who said they prefer equally Romanian and foreign brands, those who do not know the origin of the favorite brands or, where appropriate, have not been able to answer / no preference Source: own research

The main reasons given by respondents in case of preference for Romanian brands for certain categories of products

Although, overall, lagging behind foreign brands in terms of youth preference, for a low number of respondents, Romanian brands are preferred to foreign ones (except cars, in which case no respondent said he prefers Romanian products). So, those who prefer Romanian brands for different product categories are primarily motivated by: lower price than the foreign products (of the 100 young people investigated, 67 said that among the top three causes why they prefer certain Romanian brands is the lower price of products); desire to support the Romanian economy and favorable previous experience with Romanian products (indicated by most respondents). More than a quarter of the respondents also indicated as the main reasons: superior product quality and confidence in local producers. Note that $15 \%$ of respondents indicated previous unfavorable experience with foreign products, which reflects a shift towards Romanian products after experiencing dissatisfaction generated by foreign products.

Table 2. Distribution of respondents by main reasons given for preferring Romanian brands for certain product categories

\begin{tabular}{|l|c|}
\hline \multicolumn{1}{|c|}{ Reason } & $\begin{array}{c}\text { Number of respondents who } \\
\text { indicated that reason* }\end{array}$ \\
\hline High product quality & 28 \\
\hline A lower price of products & 67 \\
\hline Increased confidence in local producers & 30 \\
\hline Desire to support the Romanian economy & 53 \\
\hline Previous favorable experience with Romanian products & 50 \\
\hline Previous unfavorable experience with foreign products & 15 \\
\hline
\end{tabular}




\section{The main reasons given by respondents in case of preference for Romanian brands for certain categories of products}

Regarding foreign brands, preferred to Romanian brands (except brands of food products), they are first in the options of youth mainly due to: high product quality (of the 100 young people investigated, 83 showed among the top three reasons for the preference for foreign brands the fact that foreign products are superior in terms of quality), better value for money, favorable previous experience with foreign products (over $60 \%$ of youth indicated these reasons). Comparing the share of those who prefer Romanian products because of the unfavorable experience with foreign products, the percentage of those who prefer foreign products as a result of dissatisfaction generated by the Romanian products is lower $(10 \%)$, reflecting basically that a greater number of youngsters were dissatisfied after consumption of foreign brands than the Romanian ones.

Table 3. Distribution of the main reasons given by the respondents who prefer foreign brands for specific product categories

\begin{tabular}{|l|c|}
\hline \multicolumn{1}{|c|}{ Reason } & $\begin{array}{c}\text { Number of respondents } \\
\text { who indicated that reason* }\end{array}$ \\
\hline High product quality & 83 \\
\hline A better value for money compared to Romanian products & 62 \\
\hline Distrust in domestic producers / products & 14 \\
\hline Previous favorable experience with foreign products & 62 \\
\hline Previous unfavorable experience with Romanian products & 10 \\
\hline The products are not manufactured in Romania & 1 \\
\hline The reputation of the producers & 1 \\
\hline
\end{tabular}

* Each respondent indicated within 3 reasons, the most important Source: own research

\section{Conclusions}

Following the research, conducted on a sample of 100 students, aged 18-30, we found that they prefer in a greater extent Romanian food products compared to foreign ones (over 50\% stated, however, that he prefers equally two categories of brands). On the other hand, for products encompassing high technology (cars, appliances and electronics) and for fashion products (clothing and footwear), over 50\% of respondents prefer foreign brands. The least known brands by the respondents proved to be brands from the following categories of products: alcoholic beverages, cleaning products, foods and cosmetics, these recording the highest percentages of respondents who have not known the origin of favorite brand or not able to answer / do not have preferences. The main reasons given by respondents underlying preference for certain categories of Romanian products are lower price compared to the foreign products; desire to support the Romanian economy and favorable previous experience with Romanian products. In the case of foreign brands, the preference for certain product categories was justified in the light of particular reasons: high product quality, better value for money, favorable previous experience with foreign products.

Starting from the results of research, these can constitute hypotheses for future researches, the issue being possible to be investigated by conducting thorough representative studies at national / regional level etc. on other age segments and / or 
groups. Also starting from the main reasons given by respondents as underpinning the preference for local or foreign brands, one can consider in a future research their identification for each product category, and even for different product. Not at least, investigating the reasons underlying consumer preferences can be achieved through qualitative research in order to identify of those that consumers are unaware or unwilling to declare.

\section{References}

Dătculescu, P. (2012), Cercetarea practică de marketing, Editura Brandbuilders Grup, Bucureşti.

Dătculescu, P. (2006), Cercetarea de marketing, Editura Brandbuilders Grup, Bucureşti.

Kumar V., Aaker, D.A., Day G.S. (1999), Essentials of Marketing research, John Wiley \& Sons, Inc., New York Chichester Weinheim Brisbane Singapore Toronto.

Popescu, I.C. (2002), Cercetări calitative de marketing Chapter, în the Cătoiu, I. (coord.), Cercetări de marketing, (pp. 191-226), Uranus Publisher, Bucureşti.

Săndulescu L. (2015, September, 18), Top 100 cele mai puternice branduri romanesti, Revista Biz available at: http://www.revistabiz.ro/top-100-cele-mai-puternicebranduri-romanesti/;

Ţimiraş, L. (2016), Young People's Preferences For Romanian Agro Alimentary Goods, Studies and Scientific Researches. Economics Edition, Special Issue, available at: http://sceco.ub.ro/index.php/SCECO/article/view/353.

Revista Piaţa (2008, Iunie, 21), Brandul romanesc fata cu globalizarea, available at: http://www.revista-piata.ro/Marci_romanesti-id168.html.

Revista Piaţa (2008, November, 20), Local vs strain: alimente romanesti, cosmetice din import, available at: http://www.revistapiata.ro/Local_vs_strain_alimente_romanesti_cosmetice_din_import id4290.html. 